\title{
The Importance of Attribution of Health Services for Primary Health Centre According to the Farmer in Simpang Empat District, Karo Regency
}

\author{
Destanul Aulia ${ }^{1}$, Eddy Syahrial ${ }^{3}$ \\ Public Health Faculty \\ Universitas Sumatera Utara \\ Medan, Indonesia \\ destanul.aulia@usu.ac.id \\ syahriaaledy@yahoo.com
}

\author{
Sri Fajar $\mathrm{Ayu}^{2}$ \\ Faculty of Agriculture \\ Universitas Sumatera Utara \\ Medan, Indonesia \\ srifajar.ayu@gmail.com
}

\begin{abstract}
The basic objective of restructuring Primary Health Service such as Puskesmas is to strengthen the function of public health efforts and individual health efforts, so that the community as the user of Puskesmas health services can make the Puskesmas as a place for health, not just facilities for the sick. Puskesmas must continue to fix themselves from the elements that are considered most important by the patient and his family. This is so that Puskesmas become health services that have a positive image in every society and ideal health services. The purpose of this study is to analyze the importance of the health service attributes of the Puskesmas and to see the comparative importance of the farmers. The method used is conjoint and descriptive quantitative. The result of the study shows that the highest attribute value of the health center by farmers is quality of services, after that is communication of health center and accessibility of health service of puskesmas. Meanwhile, the result of diagnosis is the last for farmers. It is suggested to Puskesmas to start to fix elements by improvement of quality, communication and accessibility, then explain the diagnosis correctly by competent human resources.
\end{abstract}

Keywords - Health Care Atribute; Primary Health Care Center; Farmer; Importances Value

\section{INTRODUCTION}

All sectors of public services are required to get a touch of innovation by the government. One of the public services in health is Puskesmas. First-level regions are areas covered by decentralization powers. Decentralization at the first level of government is a step in realizing a more quality public service. Similarly, Puskesmas, its services must always be improved from time to time.

A good Puskesmas is required to have an apparatus that provides health services wholeheartedly, empathize, work in accordance with standard operating procedure (SOP) [1]. As a part of public services, the formulation of Puskesmas should also be built within the framework of regional autonomy, service standards formulated together with involving various parties so that more innovative [2], [3]. The majority factor of Indonesian labor in rural areas working in the agricultural sector, is at risk for health problems related to farmers and the environment. Should the concept of health services offered are also appropriate to social factor's demography, lifestyle, psychosocial and farming work environment [4]. The concept of Puskesmas can be built based on the community's lifestyle, population and main program of the Puskesmas itself [5]. More precisely, Puskesmas should be built to answer the wishes of the community.

Puskesmas is an organization that offers services, so the concept of interaction between service providers and consumers of products will be different from organizations that offer goods in a physical form. In the service, customer satisfaction is a vital indicator of quality service [6]. Quality of service in service companies is very important for the customer. Customers not only judge from the results of services but also from the service-delivery process [7]. Puskesmas service is more likely to relation or relationship between service provider and consumer (patient). The main product offered by Puskesmas is not physical, but offers a relationship. Relationship problems become uniqueness for Puskesmas when compared with market of goods. Related to the relationship, Puskesmas should prioritize the quality of human resources, quality of the process and physical without neglecting product quality, place and promotion. The product of puskesmas service is also difficult to measure. It can only be experienced by consumers. In addition, Puskesmas service is also location-based as a result it cannot move.

Location differences cause differences in patient characteristics that will affect the concept of the primary health care center, although not very different from the concept of geographical characteristics, population and its 
basic services. The existence of decentralization or regional autonomy can provide benefits primarily in improving the quality of primary health care services [5], [8]. The services can be categorized as a good service or not in accordance with the expectations from the community. However, in realizing the service that matches consumer expectations is not a practical thing. The process of upgrading the service should begin gradually.

In general, the following is the steps in performing the $\mathrm{P}$ uskesmas design to be more qualified [9].

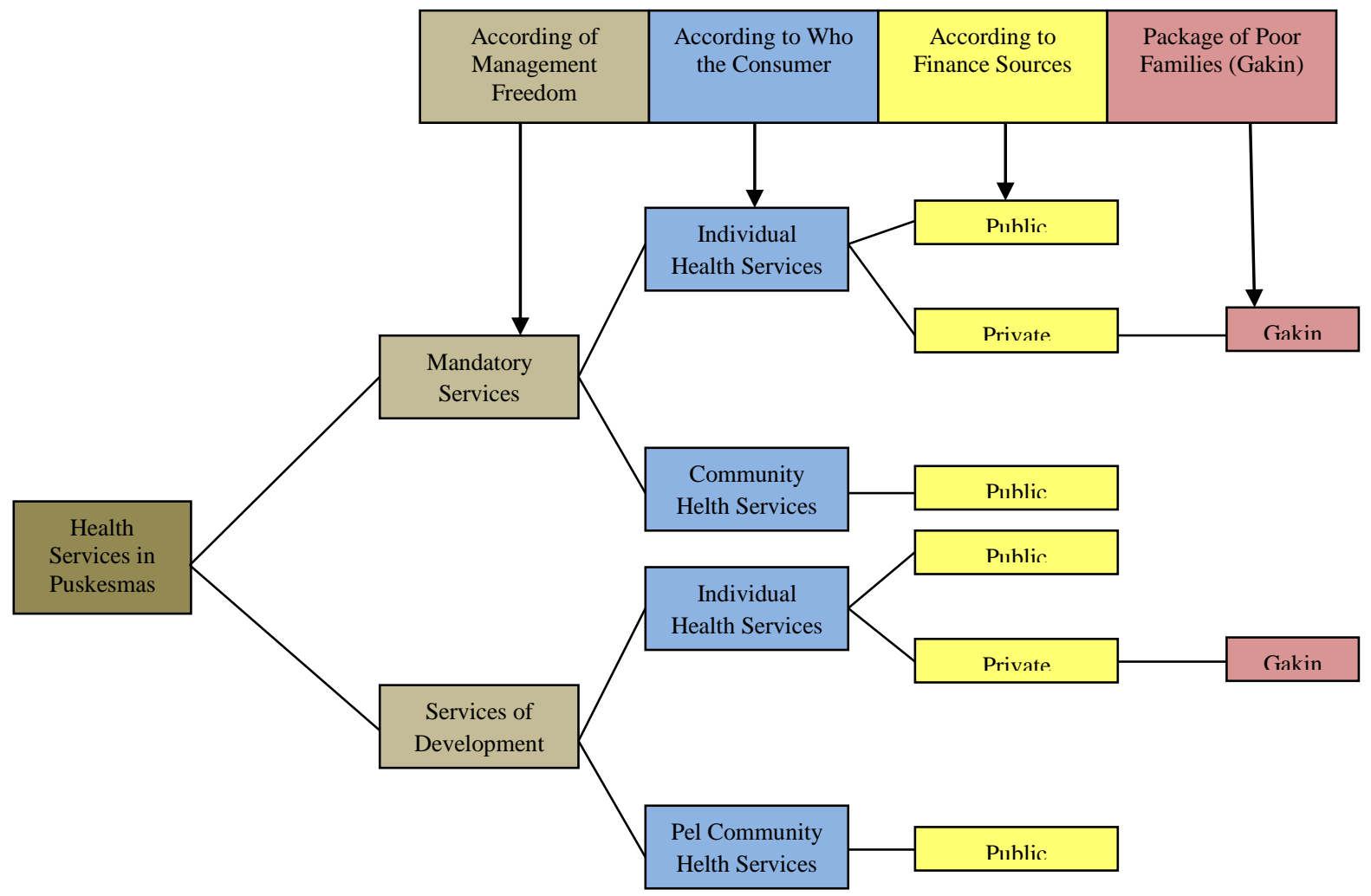

Figure 1. Steps to Design Puskesmas

The various elements that are closely related to the primary health care center service are the accessibility, communication or interaction, the quality of services provided and the results from the examination [10]. Accessibility should be supported with appropriate service quality. This is because the local population is far away to gain access to referrals to larger institutions (hospitals). Of course, it becomes a big task for the provider to increase its capacity in order to obtain consumer satisfaction, minimize referrals so that farmers can save costs and time [11]. This study aims to analyze the priority element of Puskesmas service according to farmer preference as a consumer. Through the result analysis, it is hoped that the development or improvement of Puskesmas services can be done gradually in accordance with the priority scale according to the preference of the farmer as their patient.

\section{METHOD}

This research was conducted in Kecamatan Simpang Empat, Karo. Sample taken is 106 horticulture farmers, picked purposively (horticultural farmers claiming using primary health care center services in Kecamatan Simpang Empat, Karo). The study design was a preference survey. The method of data analysis used conjoint analysis by calculating relative importance value. It manually can use the formula:

$$
\sum_{i=1}^{n} \mathrm{Wi}=1 \quad W 1=\frac{\mathrm{Ii}}{\sum_{\mathrm{i}=1}^{\mathrm{n}} \mathrm{Ii}}
$$

The relative importance value calculated using SPSS 20 applications by analyzing the Importance Values. Attributes analyzed are:

1. Accessibility consisting of sub-attributes: opening hours (operational), location of primary health care center (puskesmas), administrative service process and time queue.

2. Communication consisting of sub-attributes: communication, procedure of health center, examination procedure, explanation how to avoid disease. 
3. Treatment outcomes consisting of an explanation of subattributes: type of disease, blood test results, physical examination results, symptoms of illness and time back to work.

4. Quality of service consists of sub-attributes: cleanliness of the buildings, services provided by health personnel, responses to patient complaints, doctor's diagnosis and attitudes of medical personnel.

\section{RESULT}

Simpang Empat Sub-district is one of the horticultural centers in Karo Regency. In 2017, the total population of Simpang Empat is 20,739 inhabitants. The health facilities in this area consist of one health center and 11 sub health centers. However, the merely active one is the Puskesmas. While in terms of human resources, in 2017 there are only four doctors and 17 nurses, while the midwife is more dominant is 24 people [12].

\section{Attribute Interest Value}

Puskesmas may always receive sufficient appreciation from patients, because other than as a referral of mild illness, it is also the health service closest to the farmer's residence. However, this should not be the ultimate satisfaction for this institution in performing its duties as a public service. Puskesmas must always improve their services from time to time. This is because one of the efforts in winning the competition is by improving the quality of service. It is also accompanied by providing services in accordance with the customer expectations. So that leads to the appreciation accompanied by patient satisfaction and loyalty.

The development should follow the development of the community in the working area of the Puskesmas. So that the process of change made by the Puskesmas is not opposed to the consumer. To improve the Puskesmas service to be better, then through the analysis result obtained the total value of interest (TIV) given to the four farmers attributes provided, namely:

Grafik 1. Importances Values of Atributes

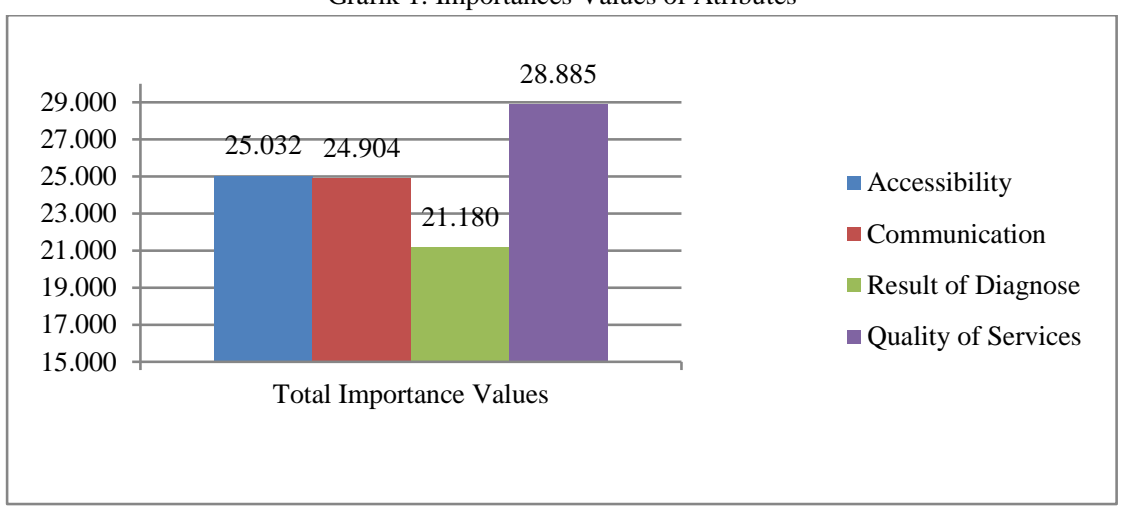

Sources: Output SPSS

Graph 1 shows that the attribute with the highest importance value is the quality of services of the Puskesmas with TIV is 28,885 . The average importance value for each attribute is 5.77. The attribute with the second TIV is accessibility that is 25.032 with an average of 6.26. For third position is communication with value of TIV 24,904 and average 6,23. The lowest TIV score was the result of treatment with a value of 21,180 and an average of 4.24.

\section{Value of Sub Attribute Interests}

Partially, the importance values (IV) according to sub attributes are as follows:
TABLE 1. IMPORTANCE VALUES MENURUT SUB ATRIBUT

\begin{tabular}{|c|c|c|c|}
\hline No & Atribut & Sub Atribut & $\begin{array}{c}\text { Importance } \\
\text { Values }\end{array}$ \\
\hline \multirow{4}{*}{1.} & \multirow{4}{*}{ Accessibility } & Bussiness hours & 7,109 \\
\hline & & Location & 6,812 \\
\hline & & Administration Services & 5,024 \\
\hline & & Time for Queued & 6,087 \\
\hline \multirow{4}{*}{2.} & \multirow{4}{*}{ Communication } & Communication with Institution & 5,397 \\
\hline & & Procedure of Puskesmas & 8,153 \\
\hline & & Procedure of Check Up & 6,145 \\
\hline & & Strategy to avoid disease & 5,209 \\
\hline \multirow{5}{*}{3.} & \multirow{5}{*}{$\begin{array}{l}\text { Result of } \\
\text { Diagnose }\end{array}$} & Type of Disease & 4,431 \\
\hline & & Reslut of Blood Check Up & 3,988 \\
\hline & & Result of Physical Examination & 3,870 \\
\hline & & Symptoms of Disease & 5,635 \\
\hline & & Time to Get Back to Work & 3,256 \\
\hline \multirow{5}{*}{4.} & \multirow{5}{*}{$\begin{array}{l}\text { Quality of } \\
\text { Services }\end{array}$} & Environmental Hygine & 4,936 \\
\hline & & Response of Medical Personel & 6,537 \\
\hline & & Complaints from Patients & 4,112 \\
\hline & & Diagnose of Doctor & 6,037 \\
\hline & & Attitude of Medical Personel & 7,273 \\
\hline
\end{tabular}


Table 1 shows that the highest Importance Value (IV) score is in sub attribute procedure of puskesmas with value 8,153 . This sub attribute lies in the communication attribute. The second highest value of is the attitude of medical personnel with value 7,273 at the attribute of quality of services. The third is 7.109 on the business hours sub attribute on accessibility. The fourth highest value is still in the accessibility attribute hat is 6,812. Meanwhile, the lowest value was in the sub attribute times to get back working with 3,256 . Sub attribute results of physical examination have 3,870 and result of blood examination has 3,988. All three are in attributes of treatment results.

\section{Attribute Importance Value}

\section{DISCUSSION}

Improving a primary health care center is not an easy matter, it is a process. The improvement is not limited to physical changes, but also about the accessibility, quality of health personnel and of course the quality of services provided. The result of analysis shows that, in general, service quality attribute is an attribute with highest TIV value. It is followed by accessibility, communication and maintainability. So according to farmers, the quality of service is a priority that must be considered in improving the quality. It is related to physical hygiene, response of doctors, care and administration side to farmer, empathy to their complaint, doctor diagnosis and attitude of doctor, nurse and administration to a farmer.

Attribute with second importance level is accessibility. Utilization of health facilities is closely related to accessing to health care facilities themselves, such as distance and availability of transportation facilities [13]. Thus, for farmers, with limited transportation facilities and the distance they will travel, they expect that their accessibility to primary health care center services is always considered in order to improve the quality of health services [11] .

Other important elements besides the accessibility are the communication. Communications and accessibility elements do not have much difference according to farmers. Communication also has a considerable relationship in maintaining patient satisfaction and loyalty [14]. It is not only limited to the interaction performed by the doctor to the patient. Although the topic that is often the subject of study is the doctor's communication only. However, in this case, communication is in the scope of the primary health care center is comprehensive. It can be from the doctors, nurses, public health personnel or the administration. The importance of communication according to the preferences of farmers, demands an increase in the quality. In addition, the primary health care center should also use simple steps to provide communicative information to farmers, so that there is no inequality of information for farmers [4].

The attribute with the lowest TIV is the treatment result. Despite being at the weakest level, the results of the treatments remain what farmers expect. Primary health care center in general is a means for farmers to treat the illness, get healing and information about the disease complaints suffered. So that the results of care should always be accessible to the farmers well, delivered with excellent communication and explanations that are easily understood by farmers. Good care results indicate that the primary health care center is reliable in establishing diagnoses and medical measures [6], [1] .

\section{Sub Attribute Importance Value}

The sub-attribute with the highest importance value is the Puskesmas procedure. Farmers always considered the procedures as a very important factor. As a public service providers it certainly has a service standard that is approved and must be implemented by every element that is bound to the primary health care center. Each public service must have a service standard and be published as a guarantee of certainty for the recipient of service. Procedures as standardized service arrangements for primary health care center service recipients are the paths that must be passed by every service recipient. The clarity of the service flow is often unknown to patients visiting the primary health care center, thus makes it difficult to understand for to do first and what to prepare for the Puskesmas [5], [8]

The second importance sub attribute is the attitude of medical personnel.The attitude of health workers, doctors, administrators, nurses and other health workers is a matter of concern [15 ]. Good human-to-human relationships between health workers and patients in the delivery of health services, shape the patient's positive perception and will contribute to improve the public health center image [16 ]. At the third level, is the opening hours and location of the primary health center. These two sub-sections are part of the attribute accessibility. Utilization of health facilities is closely related to accessing to health care facilities themselves, such as distance and availability of transportation facilities [13]. Changing the accessibility physically is not an easy thing to do. This is because the physical health center is a pre-tool. This activity will drain enormous time and cost. So in improving the accessibility to farmers, it must use innovation, both in the field of program and the empowerment of facilities. In the program area, health workers should be active outside the building and more functioning within the community, conduct direct 
monitoring and discussion without stopping the obligation inside. In the field of empowerment of facilities, can be done with the increase of ambulance mobilization in the work area.

The quality of primary health care center services is influenced by various factors such as the reliability, the guarantee given, the empathy and the physical health center itself. Time-wasting elements, less-skilled personnel, lack of empathy and information limitations make the patient feel less satisfied [15]. As a public service center, primary health care center should always appear with the priority of customer satisfaction. Management of patient satisfaction is an invaluable foundation for improving the quality of primary health care center [7], [6], [11].

\section{CONCLUSION}

1. Farmers' preference indicates that in general, the most important attribute in improving a health care center quality is the quality of services.

2. Partially, the highest importance is its procedure.

3. Communication and information are very important for farmers. .

\section{RECOMMENDATIONS}

1. The health care center suggested to be more active outside the building without leaving obligation inside and always empower farmer experience.

2. The Government should support and restructure the primary health care center by always considering the preferences of farmers as consumers.

3. Community can always provide positive and open input to the health care center to improve its quality.

\section{ACKNOWLEDGMENT}

The acknowledgment is to Universitas Sumatera Utara Research Institute that has provided moral and material assistance in the implementation of the research scheme TALENTA Applied Research (Penelitian Terapan) 2017 and this publication, which also become the funding of this research.

\section{REFERENCES}

[1] Novitasari, Dian, Mardiyono, Abdul Wahid, "An Idoal and Idaman Local Clinic's Service In Improving the Citizens Health", "Pelayanan
Puskesmas idaman dan idola dalam rangka meningkatkan kesehatan masyarakat", JAP, Vol. 2 No. 4 pp.740-746, 2014, in press.

[2] Kabir, "Pelayanan publik dalam kerangka otonomi daerah", Proceeding SENDI_U UNISBANK 2: Semarang, Juli, 2016, in press

[3] Yani, Andi Ahmad, "Otonomi daerah dan kualitas pelayanan publik Kepulauan Spermonde di Prov. Sulawesi Selatan; kasus di Kecamatan Ujung Tanah, Kota Makassar dan Kecamatan Liukang Tangaya, Kabupaten Pangkep", ResearchGate, July, 2010, in press.

[4] Susanto, Tantut, Retno Purwandari, Emi Wuri W, "Occupational Health Nursing Model-Based Agricultural Nursing: A Study Analyzes of Farmers Health Problem", "Model kesehatan keselamatan kerja berbasis agricultural nursing: studi analisis masalah kesehatan petani", Jurnal Ners Vol. 11 No. 1 April, pp. 45-50, 2016, in press.

[5] Faisol, Amir, "Konsep Puskesmas baru di era otonomi daerah (suatu kajian di Puskesmas Kabupaten Pasir Kalimantan Timur)", UNAIR: Surabaya, 2001, in press.

[6] GS, Achmad Daengs, Mahjudin, Mashudah Hufron," Increasing the service quality for customer satisfaction", "Peningkatan kualitas layanan untuk kepuasan pelanggan", Journal of Economics, Business and Accountancy Ventura, Vol. 15 No. 3, December 2012, pp. 423 442 , in press.

[7] Noerchoidah, "Pengaruh kualitas pelayanan terhadap kepuasan pelanggan (Studi Orenztaxi) di Surabaya", BISMA, Vol. 9 No. 2, April, 2017, in press.

[8] Sadaly, Hariyanti and Rahmat Herutomo (editor) "Menilai Otda dari kemajuan pelayanan publik", Proceeding SMERU: Makasar, Juni 2003 , in press.

[9] Hoedijono, Sulistiyawati and Suharmiati, "Pengembangan model pelayanan Puskesmas mandiri di era desentralisasi (studi kasus di Propinsi Kalimantan Timur", Buletin Penelitian Sistem Kesehatan Vol. 6, No. 2, December 2003, pp. 92-110, in press.

[10] Tucker, Jessie.L, "The moderators of patient satisfaction", Journal of Management in Medicine, Vol. 16 Iss 1 pp. 48 - 66, 2002, in press.

[11] Jones, Carol Adaire, Timothy S. Parker, Mary Ahearn, Ashok K. Mishra and Jayachandran N.V, "Health status and health care access of farm and rural populations", Economic Research Service, U.S Department of Agriculture, August 2009, in press.

[12] BPS, "Kecamatan Simpang Empat dalam angka 2017”, CV. E'Karya: Karo, 2017, in press.

[13] Adriana, Nara, LP Lila Wulandari, Dyah Pradnyaparamita Duarsa, "Access to health service related to use of Antenatal Care facilities at the Kawangu Health Centre - East Sumba", "Akses pelayanan kesehatan berhubungan dengan pemanfaatan fasilitas persalinan yang memadai di Puskesmas Kawangu", University of Udayana: Bali, Public Health and Preventive Medicine Archive Volume 2 No. 2, December 2014, in press.

[14] Wahyuni, Tiara, Amel Yanis, Erly Erly, "Hubungan komunikasi dokter-pasien terhadap kepuasan pasien berobat di Poliklinik RSUP DR. M. Djamil Padang", Andalas University: Padang, Jurnal Kesehatan Andalas Volume 2 No. 3, 2013, in press.

[15] Azkha, Nizwardi and Deni Elnovriza, “Analisis tingkat kepuasan klien terhadap pelayanan kesehatan di puskesmas dalam wilayah Kota Padang tahun 2006". Andalas University: Padang, Jurnal Kesehatan Masyarakat Andalas Volume 1 Nomor 2, 2007, in press.

[16] Tanan, Lohafri, Indar, Darmawansyah, "Analysis of patient satisfaction in Bara Permai public health center Palopo City", "Analisis tingkat kepuasan pasien di puskesmas Bara Permai Kota Palopo", Hasanuddin University: Makassar, Jurnal AKK Volume 2 Nomor 3, September 2013, in press. 